\title{
The rate of contamination, occurrence and molecular characterization of Pseudomonas isolates in vegetables collected from different regions of Sulaimani province, Iraq
}

\author{
Omer Ahmed Ghafour, Chawan Nawzad, Jutyar Kazm Khalaf, Niga Karim Bchkol, Ashna Latif Sharif, Shaida \\ Rahim Watman, Taib Ahmed Hama Soor* \\ Medical Laboratory Department, Technical College of Health, Sulaimani Polytechnic University, Sulaimani, Iraq
}

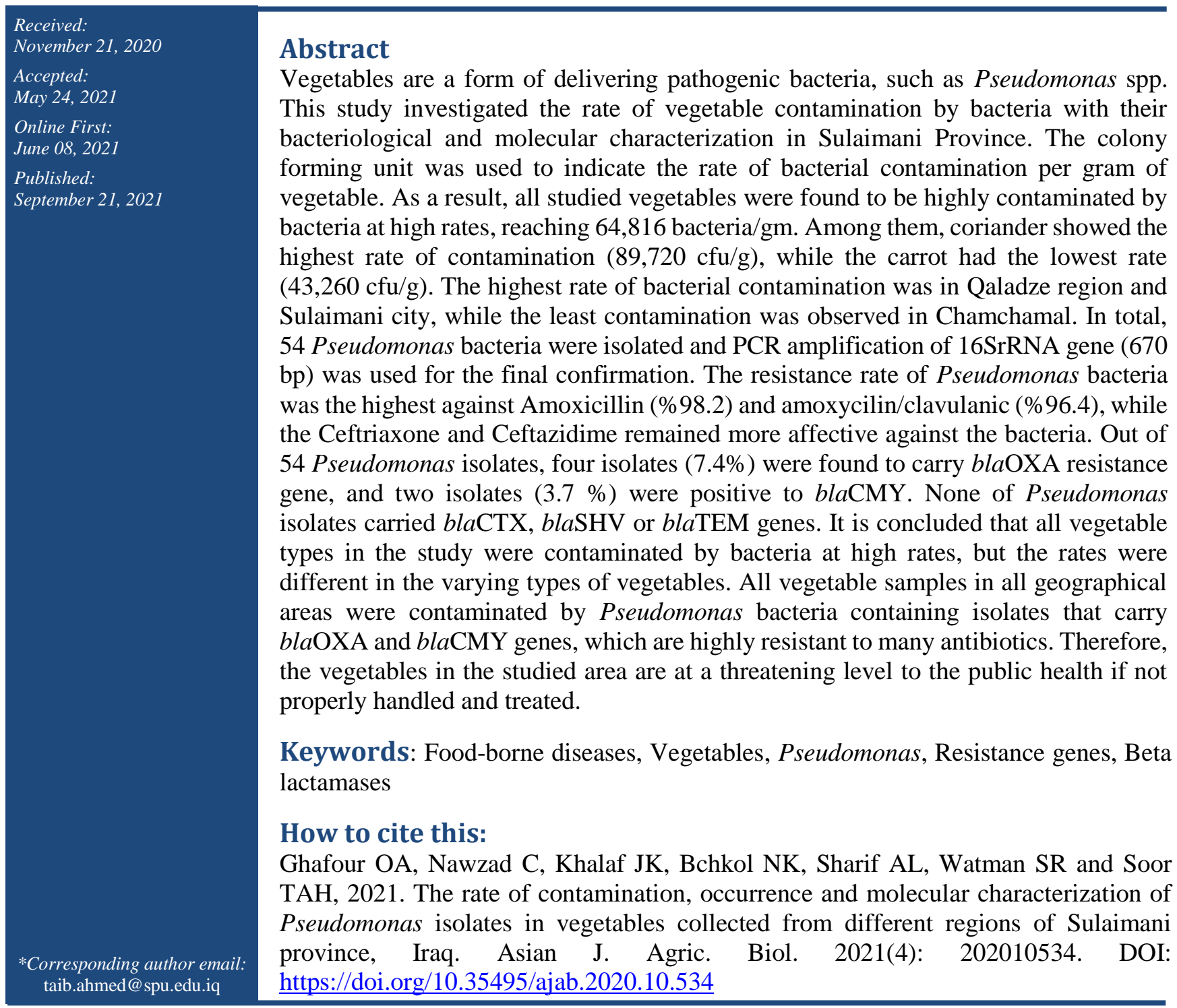

This is an Open Access article distributed under the terms of the Creative Commons Attribution 3.0 License. (https://creativecommons.org/licenses/by/3.0), which permits unrestricted use, distribution, and reproduction in any medium, provided the original work is properly cited. 


\section{Introduction}

Food borne bacteria diseases are problematic and are clinically important. In addition to the pain of illness, it also causes economic losses. One third of people in industrialized countries experience food-borne diseases yearly, reaching six to 81 million cases (Alzoreky and Nakahara, 2003; FAO/WHO, 2005). In the United States, food-borne diseases have affected around 76 million people in one year, including 5,000 deaths (Fan et al. 2009).

Fresh vegetables and fruits are known as a source of essential dietary nutrients for consumers (Lerici et al., 2000), but they can also become a risk of transmitting bacterial diseases (Beuchat, 2002). The number of illness cases are growing with increasing consumption of vegetables and fruits (Pathogens et al., 2014). It has been shown that vegetables have a bigger role in transmitting food borne diseases in comparison to fruits (Garg et al., 2010). Many types of pathogenic bacteria, such as Shigella spp., Listeria monocytogenes, Salmonella spp., Shiga toxigenic E. coli (STEC), and Campylobacter spp., have been found to be associated with food-borne illnesses in ready-to-eat vegetables (European Commission, 2002).

The genus of Pseudomonas bacteria is the most diverse and common type of bacteria (Franzetti and Scarpellini, 2007; Molina and Pimentel, 2013). Some species of Pseudomonas can be found in all countries and in any kind of environment ( Huis in 't Veld, 1996; Molina and Pimentel, 2013). In addition, it is also known as the most common psychrotrophic bacteria that causes food spoilage, especially in humid aerobic conditions (Borch et al., 1996; Dainty and Mackey, 1992), and in poultry (Gallo et al., 1998).

In Iraq, people consume large amounts of varying vegetables daily. Some of the vegetable plants are irrigated with sewage water, so the chance of contamination with pathogenic bacteria is extremely high. Therefore, in this study, an attempt was made to find the rate of vegetable contamination by common bacteria and find the rate of contamination by Pseudomonas Spp. in different regions of Sulaimani province. In addition, the antibiotic sensitivity and the rate of beta lactamase resistance gene was detected using PCR.

\section{Material and Methods}

\section{Sampling}

In this survey, the contamination rate of bacteria in vegetables was investigated. Vegetable wash was used to isolate and culture the bacteria and total bacteria count in 54 vegetable samples (10 carrots, 10 leeks, 10 celeries, 10 radishes, and 10 corianders). This was performed in Sulaimany city from October to November 2019. Samples were collected in five regions and towns (14 in Sulaimany, 10 in Chamchamal, 10 in Bazian, 10 in Qaladze, and 10 in Kalar). The samples were collected and put into sterile poly bags under aseptic condition to avoid contamination before transporting to the laboratory. The samples were then processed in the lab by suspending 25 grams of each type of vegetable in 225 $\mathrm{ml}$ of normal saline (Anonymous, 2014). The mixture was put into a shaking incubator for 30 minutes at 250 RPM (rotation per minute) and one $\mathrm{ml}$ of the wash was taken into an Eppendorf tube for use.

\section{Total bacterial cell counting}

Total live bacterial cell count was performed using the colony forming unit method on nutrient agar, MacConkey agar, and Mannitol Salt agar (Neogene Culture Media, Heywood, UK). After inoculation, all the plates were incubated at $37^{\circ} \mathrm{C}$ for 24 hours, except the bacterial culture Cetrimide agar plate that was used to isolate pseudomonas bacteria; this was incubated at room temperature. The colonies were then counted to estimate the number of growing colonies on each plate for every sample.

\section{Isolation of Pseudomonas spp.}

Bacteriological swabs were used to collect bacterial suspension and to culture them onto MacConkey agar and Cetrimide agar. After 18-24 hours of incubation at $37{ }^{\circ} \mathrm{C}$, pink colonies on the MacConkey agar were chosen for further confirmation by culturing the bacterial suspension onto Cetrimide medium. Pseudomonas made a large mucoid green colony on the Cetrimide agar (Taylor et al., 1977). Biochemical tests were carried out for identification and confirmation of pseudomonas species using oxidase and catalase tests. The final confirmation was made by PCR amplification of 12SrRNA using primers specific to Pseudomonas spp. and to Pseudomonas aurogenosa. 


\section{Antimicrobial Susceptibility Testing}

Susceptibility testing was performed using the KirbyBauer disk diffusion method on Mueller Hinton agar. 6 different types of antibiotics were used, including ceftriaxone $(\mathrm{CRO} 30 \mu \mathrm{g})$, ceftazidime $(\mathrm{CAZ} 30 \mu \mathrm{m})$, cefotaxime $(\mathrm{CTX} 30 \mu \mathrm{m})$, amoxycilin/clavulanic acid 2/1 (AMC), meropenem (Mem10 $\mu \mathrm{m}$ ), and amoxicillin $(\mathrm{AX} 25 \mu \mathrm{m})$ (Bioanalyse, Ankara, Turkey).

\section{Polymerase Chain Reaction (PCR)}

DNA of bacteria was extracted by the boiling method at $99{ }^{\circ} \mathrm{C}$ in 100 microliters of sterile distilled water for 10 minutes (Dashti et al., 2009). To confirm pseudoscience species, a set of primers were used. Another set of specific primers were used to confirm pseudomonas aeruginosa (El-roos et al., 2013; Mohammed et al., 2015). Primers that were used to detect five beta lactamase resistance genes (blaCTX, CMY, SHV, TEM, OXA) were also used to detect the existence of resistance genes in pseudomonas species (Ahmed et al., 2007 \& 2009).

PCR was performed in a 20-microliter reaction mixture using an applied bio system thermocycler. The mixture was composed of $10 \mu \mathrm{L}$ of $2 \mathrm{X}$ premix Red Taq polymerase, $2 \mu \mathrm{L}$ DNA, $1 \mu \mathrm{L} \mathrm{H} 2 \mathrm{O}$, and $2 \mu \mathrm{L}$ primers. The PCR condition started at $95^{\circ} \mathrm{C}$ for $5 \mathrm{~min}$, and then 35 cycles of $95{ }^{\circ} \mathrm{C}$ for $30 \mathrm{sec}, 55^{\circ} \mathrm{C}$ for 30 sec, and $72{ }^{\circ} \mathrm{C}$ for $30 \mathrm{sec}$, with a final extension temperature of $72{ }^{\circ} \mathrm{C}$ for $7 \mathrm{~min}$. $10 \mu \mathrm{L}$ of the PCR mixture was run on $1 \%$ agarose gel using DNA gel electrophoresis system at $100 \mathrm{~V}$ for $30 \mathrm{~min}$. Then the images of DNA were taken using smart Doc gel imaging system.

\section{Results}

The rate of bacterial contamination in vegetables To know the rate of bacterial contamination among different kinds of vegetables in different locations in Sulaimani Province, varying kinds of vegetable samples were aseptically collected for laboratory processing and bacteriological studies. Five types of vegetables (leek, carrot, celery, radish, and coriander) were collected in five different locations (Sulaimany, Chamchamal, Bazian, Kalar and Qaladze).

\section{Total bacterial counting:}

\section{Total bacterial counting on nutrient agar}

Since nutrient agar is a non-selective medium and all types of bacteria can grow on it, the number of bacteria on this agar was counted to detect the total bacterial contamination in vegetables. From 50 samples of different vegetables, the rate of contamination by all types of bacteria was very high $(64,816$ bacteria/gm). Coriander recorded the highest number of contamination $(89,720 \mathrm{cfu} / \mathrm{g})$, while the carrot had the lowest rate of contamination $(43,260 \mathrm{cfu} / \mathrm{g})$. The rate of contamination in leek, celery and radish were $77,060 \mathrm{cfu} / \mathrm{g}, 58,920 \mathrm{cfu} / \mathrm{g}$, and 55,120 cfu/g, respectively (Figure 1A). The number of bacteria (cfu) on nutrient agar was also counted according to different regions. Qaladze had the highest rate of contamination $(93,040 \mathrm{cfu} / \mathrm{g})$, while Kalar had the lowest rate $(40,200 \mathrm{cfu} / \mathrm{g})$ (Figure 1B).

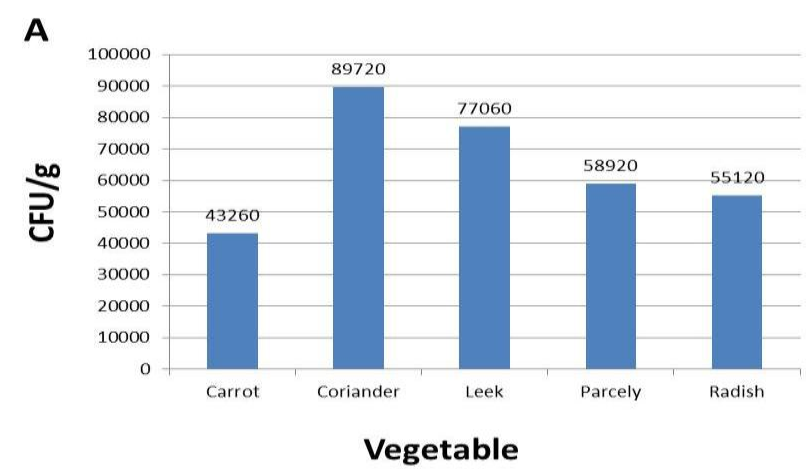

B

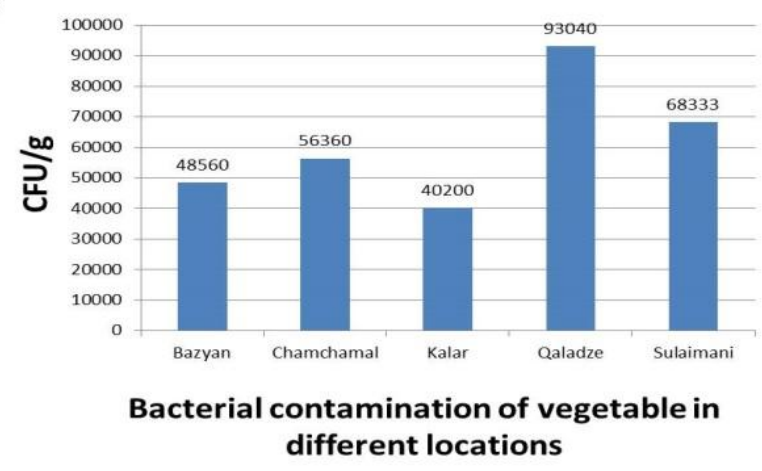

Figure-1. The rate of total bacterial contamination in vegetables.

A. The rate of contamination according to different types of vegetables.

B. Bacterial contamination rate of vegetables according to different geographical areas.

\section{Total bacterial counting on MacConkey agar}

In this study, MacConkey agar was used to indicate the rate of Enterobacteriaceae contamination in vegetables, which may source from fecal contamination. This may cause fecal oral transmission of pathogenic bacteria (Warburton, et al. 1994). The rate of enteric bacteria contamination in vegetables 


\section{Omer Ahmed Ghafour et al}

was very high $(26,044$ bacteria/gm). The highest rate was recorded in celery $(39,640 \mathrm{cfu} / \mathrm{g})$, while the lowest rate was detected in radish $(10,880 \mathrm{cfu} / \mathrm{g})$. The rate of contamination in leek, coriander and carrot were $25,960 \mathrm{cfu} / \mathrm{g}, 27,780 \mathrm{cfu} / \mathrm{g}$, and $25,960 \mathrm{cfu} / \mathrm{g}$, respectively (Figure 2A). In addition, the numbers of bacteria on MacConkey agar among different locations was counted. Qaladze had the highest rate of contamination of Enterobacteriaceae $(67,600 \mathrm{cfu} / \mathrm{g})$, while Kalar had the lowest rate $(3,120 \mathrm{cfu} / \mathrm{g})$ (Figure 2B).
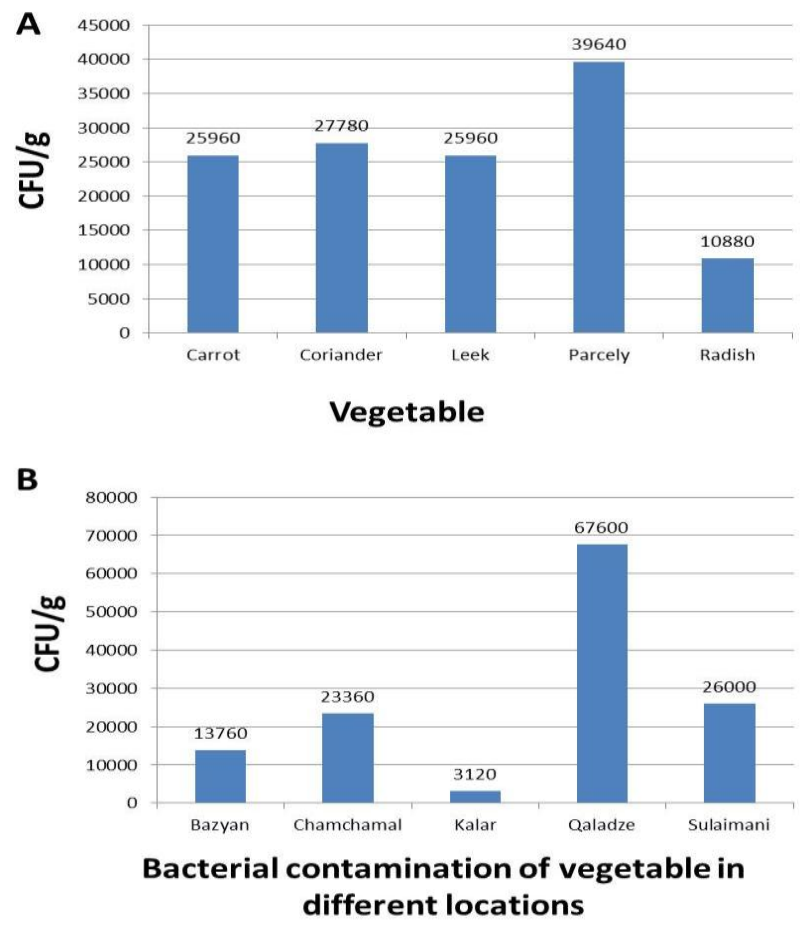

Figure-2. The rate of total bacterial contamination (Enterobacteriaceae) in vegetables.

A. The rate of bacterial (Enterobacteriaceae) contamination in different vegetables.

B. Bacterial contamination rate (Enterobacteriaceae) of vegetables according to different geographical areas.

\section{Total bacterial counting on Mannitol Salt agar}

This media was used to indicate the rate of contamination of bacteria like Staphylococcus species that can grow on high salt containing medias, such as Mannitol Salt agar. The total rate of Staphylococcus contamination in all types of vegetables was high (5,612 bacteria/gm). Radish had the highest rate of contamination $(7,960 \mathrm{cfu} / \mathrm{g})$, while leek had the lowest rate $(2,220 \mathrm{cfu} / \mathrm{g})$. The rate of contamination among carrot, coriander and celery were 7,440 cfu/g, 6,340 $\mathrm{cfu} / \mathrm{g}$, and $4,100 \mathrm{cfu} / \mathrm{g}$, respectively (Figure $3 \mathrm{~A}$ ). The same study was carried out according to different geographical places. Sulaimani had the highest rate of contamination $(8,453 \mathrm{cfu} / \mathrm{g})$, while Chamchamal had lowest rate $(280 \mathrm{cfu} / \mathrm{g})$ (Figure 3B).

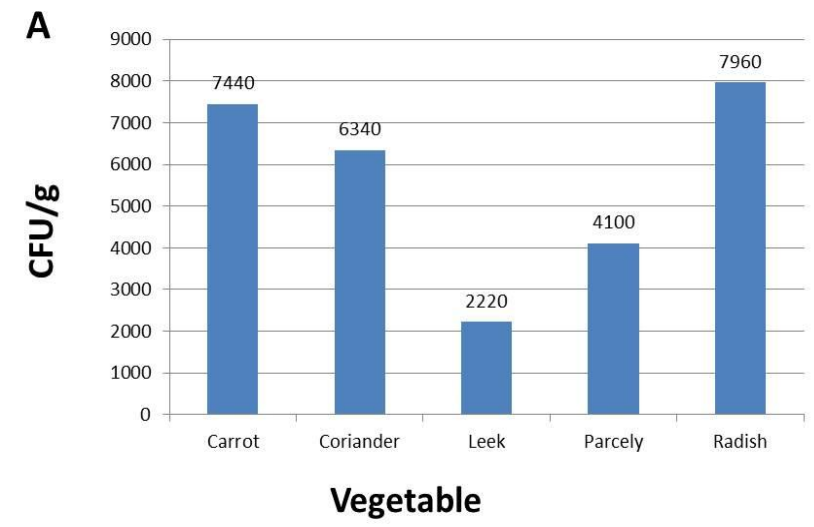

B

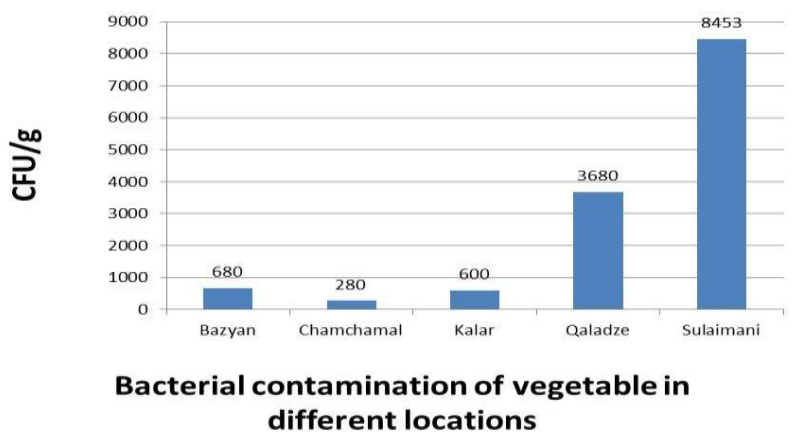

Figure-3. The rate of total Staphylococcus bacterial contamination in different types of vegetables in Sulaimani province.

A. The rate of Staphylococcus contamination in different types of vegetables.

B. Bacterial contamination rate of vegetables according to different geographical places.

\section{Isolation of Pseudomonas bacteria}

There are many sources of transmitting pathogenic bacteria to humans, one of them being vegetables (Beuchat, 2002; Pathogens et al., 2014). Pseudomonas bacteria were isolated on selective and differential media. Three methods were used to isolate and identify pseudomonas bacteria. After isolation of bacteria on MacConkey agar, the suspected colonies were further differentiated by culturing them on a selective and differential media, Cetrimide agar. Pseudomonas bacteria produce a green, fluorescent color which is a unique characteristic of Pseudomonas 


\section{Omer Ahmed Ghafour et al}

on Cetrimide agar. Positively selected colonies were then further confirmed by biochemical tests, oxidase and catalase. Pseudomonas bacteria is one of the five clinically important gram negative bacteria, which is positive to oxidase test. Therefore, this test was used to confirm pseudomonas bacteria. The last confirmation was done specifically by PCR amplification of a gene using primers specific only to Pseudomonas bacteria. In this study, 54 Pseudomonas bacteria were isolated, and for this selection, an eye observation was used to look for the development of a bright fluorescent colored colony on Cetrimide and Mueller Hinton agar media (Taylor et al., 1977).

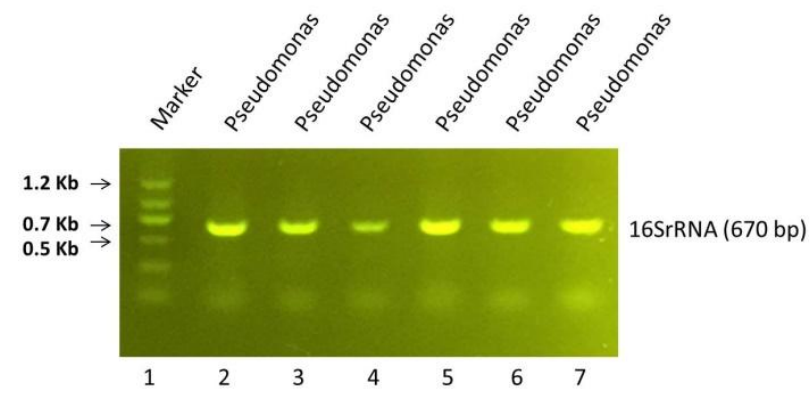

Figure-4: PCR confirmation of Pseudomonas species. 16SrRNA gene $(670$ bp) specific for pseudomonas species were amplified and run on $1 \%$ DNA agarose gel using 1.2 Kb DNA ladder.

16SrRNA gene $(670$ bp) primers specific for pseudomonas species was used for further confirmation of pseudomonas species (Mohammed et al., 2015). All of the isolated bacteria were positive for this gene (Figure 4). 16SrRNA gene specific for pseudomonas aeruginosa was then used (El-roos et al., 2013; Mohammed et al., 2015), but all of the samples were negative for this gene. Fortunately, there were no pathogenic pseudomonas aeruginosa bacteria in the vegetable samples that may threat human health.

\section{Antibiotic sensitivity testing}

An antibiotic sensitivity (or susceptibility) test was done to indicate the resistant rate of pseudomonas aeruginosa bacteria against different antibiotics. The test was performed using the Kirby-Bauer disk diffusion method on Mueller Hinton agar. Six different types of beta lactam antibiotics were used, including ceftriaxone $(30 \mu \mathrm{g})$, ceftazidime $(30 \mu \mathrm{m})$, cefotaxime $(30 \mu \mathrm{m})$, amoxycilin/clavulan acid2/1, meropenem $(10 \mu \mathrm{m})$, and amoxicillin $(25 \mu \mathrm{m})$ (bio Maxima S.A ). In this test, the rate of resistance to different antibiotics in Pseudomonas was detected. Among 54 samples of pseudomonas bacteria, the percentage rate of resistance for antibiotics was as follows: (CRO30/16.36\%), (CAZ30/16.36\%), (CTX30/52.72\%), (AMC3/96.4\%), (MEM10/25.5\%) and (AX25/98.2\%)(Figure 5).

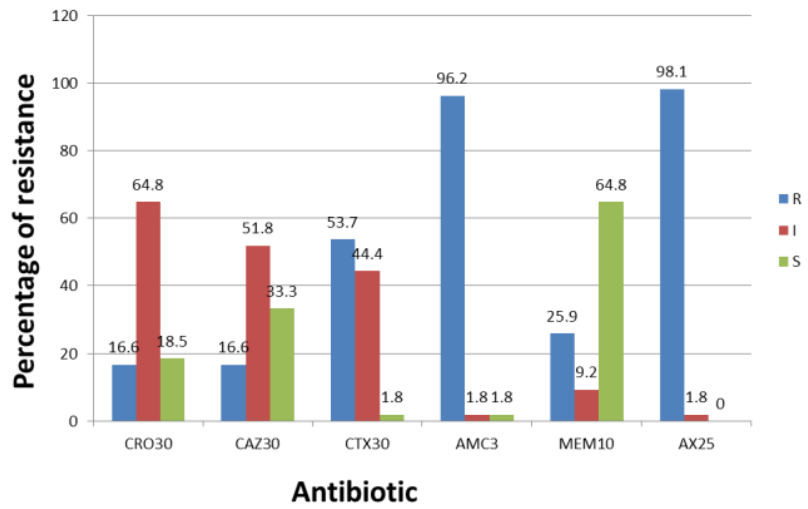

Figure-5. The rate of antibiotic resistance in Pseudomonas isolates. The rate of antibiotic resistance was indicated in 54 Pseudomonas isolates recovered from different types of vegetable. 
Omer Ahmed Ghafour et al

Table-1. Drug resistance scores of Pseudomonas isolated from vegetable samples.

\begin{tabular}{|c|c|c|c|c|c|c|}
\hline Samples & CRO30 & CAZ30 & CTX30 & AMC3 & MEM10 & AX25 \\
\hline P1 & $\mathrm{I}(17)$ & $\mathrm{R}(14)$ & $\mathrm{R}(14)$ & $\mathrm{R}(0)$ & $\mathrm{S}(17)$ & $\mathrm{R}(0)$ \\
\hline $\mathrm{P} 2$ & $\mathrm{I}(18)$ & $\mathrm{I}(15)$ & $\mathrm{R}(13)$ & $\mathrm{R}(0)$ & $\mathrm{S}(17)$ & $\mathrm{R}(0)$ \\
\hline P3 & $\mathrm{I}(18)$ & $\mathrm{I}(17)$ & $\mathrm{I}(15)$ & $\mathrm{R}(0)$ & $\mathrm{S}(20)$ & $\mathrm{R}(0)$ \\
\hline $\mathrm{P} 4$ & $\mathrm{R}(12)$ & $\mathrm{R}(12)$ & $\mathrm{R}(0)$ & $\mathrm{R}(0)$ & $\mathrm{S}(28)$ & $\mathrm{R}(0)$ \\
\hline P5 & $\mathrm{R}(10)$ & $\mathrm{R}(12)$ & $\mathrm{R}(0)$ & $\mathrm{R}(0)$ & $\mathrm{I}(15)$ & $\mathrm{R}(0)$ \\
\hline P6 & $\mathrm{S}(21)$ & $\mathrm{I}(17)$ & $\mathrm{R}(12)$ & $\mathrm{R}(0)$ & $\mathrm{S}(18)$ & $\mathrm{R}(0)$ \\
\hline P7 & $\mathrm{I}(18)$ & $\mathrm{S}(20)$ & $\mathrm{R}(14)$ & $\mathrm{R}(0)$ & $\mathrm{S}(20)$ & $\mathrm{R}(0)$ \\
\hline $\mathrm{P} 8$ & $\mathrm{I}(17)$ & $\mathrm{S}(18)$ & $\mathrm{I}(16)$ & $\mathrm{R}(0)$ & $\mathrm{S}(18)$ & $\mathrm{R}(0)$ \\
\hline P9 & $\mathrm{I}(18)$ & $\mathrm{S}(18)$ & $\mathrm{I}(15)$ & $\mathrm{R}(0)$ & $\mathrm{S}(17)$ & $\mathrm{R}(0)$ \\
\hline $\mathrm{P} 10$ & $\mathrm{I}(18)$ & $\mathrm{S}(19)$ & $\mathrm{I}(16)$ & $\mathrm{R}(0)$ & $\mathrm{S}(18)$ & $\mathrm{R}(0)$ \\
\hline P11 & $\mathrm{I}(15)$ & $\mathrm{I}(16)$ & $\mathrm{R}(11)$ & $\mathrm{R}(0)$ & $\mathrm{S}(16)$ & $\mathrm{R}(0)$ \\
\hline P12 & $\mathrm{I}(18)$ & $\mathrm{I}(12)$ & $\mathrm{I}(15)$ & $\mathrm{R}(0)$ & $\mathrm{S}(19)$ & $\mathrm{R}(0)$ \\
\hline $\mathrm{P} 13$ & $\mathrm{~S}(22)$ & $\mathrm{S}(20)$ & $\mathrm{I}(17)$ & $\mathrm{R}(0)$ & $\mathrm{S}(20)$ & $\mathrm{R}(0)$ \\
\hline P14 & $\mathrm{I}(18)$ & $\mathrm{I}(17)$ & $\mathrm{I}(15)$ & $\mathrm{R}(0)$ & $\mathrm{S}(18)$ & $\mathrm{R}(0)$ \\
\hline P15 & $\mathrm{R}(13)$ & $\mathrm{S}(18)$ & $\mathrm{R}(12)$ & $\mathrm{R}(0)$ & $\mathrm{S}(33)$ & $\mathrm{R}(0)$ \\
\hline P16 & $\mathrm{R}(0)$ & $\mathrm{I}(17)$ & $\mathrm{R}(0)$ & $\mathrm{R}(0)$ & $\mathrm{I}(15)$ & $\mathrm{R}(0)$ \\
\hline P17 & $\mathrm{S}(26)$ & $\mathrm{S}(27)$ & $\mathrm{I}(20)$ & $\mathrm{S}(18)$ & $\mathrm{S}(45)$ & $\mathrm{R}(0)$ \\
\hline P18 & $\mathrm{I}(17)$ & $\mathrm{I}(17)$ & $\mathrm{R}(14)$ & $\mathrm{R}(0)$ & $\mathrm{R}(10)$ & $\mathrm{R}(0)$ \\
\hline P19 & $\mathrm{I}(14)$ & $\mathrm{I}(17)$ & $\mathrm{I}(15)$ & $\mathrm{R}(0)$ & $\mathrm{S}(17)$ & $\mathrm{R}(0)$ \\
\hline $\mathrm{P} 20$ & $\mathrm{I}(17)$ & $\mathrm{I}(17)$ & $\mathrm{R}(11)$ & $\mathrm{R}(0)$ & $\mathrm{I}(15)$ & $\mathrm{R}(0)$ \\
\hline $\mathrm{P} 21$ & $\mathrm{~S}(21)$ & $\mathrm{S}(20)$ & $\mathrm{I}(18)$ & $\mathrm{R}(0)$ & $\mathrm{S}(20)$ & $\mathrm{R}(0)$ \\
\hline $\mathrm{P} 22$ & $\mathrm{I}(18)$ & $\mathrm{S}(18)$ & $\mathrm{I}(15)$ & $\mathrm{R}(0)$ & $\mathrm{S}(20)$ & $\mathrm{R}(0)$ \\
\hline $\mathrm{P} 23$ & $\mathrm{I}(17)$ & $\mathrm{I}(17)$ & $\mathrm{I}(16)$ & $\mathrm{R}(0)$ & $\mathrm{S}(20)$ & $\mathrm{R}(0)$ \\
\hline P24 & $\mathrm{R}(12)$ & $\mathrm{S}(20)$ & $\mathrm{R}(0)$ & $\mathrm{R}(0)$ & $\mathrm{S}(22)$ & $\mathrm{R}(0)$ \\
\hline P25 & $\mathrm{R}(10)$ & $\mathrm{I}(15)$ & $\mathrm{R}(0)$ & $\mathrm{R}(0)$ & $\mathrm{S}(17)$ & $\mathrm{R}(0)$ \\
\hline P26 & $\mathrm{I}(16)$ & $\mathrm{S}(21)$ & $\mathrm{R}(13)$ & $\mathrm{R}(0)$ & $\mathrm{S}(33)$ & $\mathrm{R}(0)$ \\
\hline P27 & $\mathrm{I}(18)$ & $\mathrm{I}(17)$ & $\mathrm{R}(13)$ & $\mathrm{R}(0)$ & $\mathrm{S}(30)$ & $\mathrm{R}(0)$ \\
\hline P27-A & $\mathrm{S}(21)$ & $\mathrm{I}(17)$ & $\mathrm{R}(12)$ & $\mathrm{R}(0)$ & $\mathrm{S}(22)$ & $\mathrm{R}(0)$ \\
\hline P28 & $\mathrm{I}(20)$ & $\mathrm{S}(21)$ & $\mathrm{I}(15)$ & $\mathrm{R}(0)$ & $\mathrm{S}(26)$ & $\mathrm{R}(0)$ \\
\hline P29 & $\mathrm{I}(17)$ & $\mathrm{S}(18)$ & $\mathrm{I}(15)$ & $\mathrm{R}(0)$ & $\mathrm{S}(20)$ & $\mathrm{R}(0)$ \\
\hline P30 & $\mathrm{I}(15)$ & $\mathrm{R}(13)$ & $\mathrm{R}(12)$ & $\mathrm{R}(0)$ & $\mathrm{R}(0)$ & $\mathrm{R}(0)$ \\
\hline P31 & $\mathrm{I}(17)$ & $\mathrm{R}(14)$ & $\mathrm{R}(13)$ & $\mathrm{R}(0)$ & $\mathrm{R}(0)$ & $\mathrm{R}(0)$ \\
\hline P32 & $\mathrm{I}(16)$ & $\mathrm{R}(13)$ & $\mathrm{R}(11)$ & $\mathrm{R}(0)$ & $\mathrm{R}(0)$ & $\mathrm{R}(0)$ \\
\hline P33 & $\mathrm{I}(16)$ & $\mathrm{R}(11)$ & $\mathrm{R}(0)$ & $\mathrm{R}(0)$ & $\mathrm{S}(24)$ & $\mathrm{R}(0)$ \\
\hline P34 & $\mathrm{I}(14)$ & $\mathrm{R}(14)$ & $\mathrm{R}(12)$ & $\mathrm{R}(0)$ & $\mathrm{R}(0)$ & $\mathrm{R}(0)$ \\
\hline P35 & $\mathrm{I}(14)$ & $\mathrm{I}(15)$ & $\mathrm{R}(12)$ & $\mathrm{R}(0)$ & $\mathrm{I}(15)$ & $\mathrm{R}(0)$ \\
\hline P37 & $\mathrm{I}(17)$ & $\mathrm{I}(16)$ & $\mathrm{R}(12)$ & $\mathrm{R}(0)$ & $\mathrm{S}(19)$ & $\mathrm{R}(0)$ \\
\hline P38 & $\mathrm{R}(13)$ & $\mathrm{I}(17)$ & $\mathrm{R}(0)$ & $\mathrm{R}(0)$ & $\mathrm{R}(0)$ & $\mathrm{R}(0)$ \\
\hline P39 & $\mathrm{S}(21)$ & $\mathrm{I}(17)$ & $\mathrm{R}(13)$ & $\mathrm{R}(0)$ & $\mathrm{R}(10)$ & $\mathrm{R}(0)$ \\
\hline $\mathrm{P} 40$ & $\mathrm{I}(16)$ & $\mathrm{I}(17)$ & $\mathrm{R}(12)$ & $\mathrm{R}(0)$ & $\mathrm{S}(17)$ & $\mathrm{R}(0)$ \\
\hline P41 & $\mathrm{R}(12)$ & $\mathrm{I}(17)$ & $\mathrm{R}(14)$ & $\mathrm{R}(0)$ & $\mathrm{I}(15)$ & $\mathrm{R}(0)$ \\
\hline $\mathrm{P} 42$ & $\mathrm{I}(15)$ & $\mathrm{I}(15)$ & $\mathrm{R}(10)$ & $\mathrm{R}(0)$ & $\mathrm{R}(0)$ & $\mathrm{R}(0)$ \\
\hline $\mathrm{P} 43$ & $\mathrm{I}(16)$ & $\mathrm{I}(17)$ & $\mathrm{I}(15)$ & $\mathrm{R}(0)$ & $\mathrm{R}(0)$ & $\mathrm{R}(0)$ \\
\hline $\mathrm{P} 44$ & $\mathrm{I}(17)$ & $\mathrm{I}(17)$ & $\mathrm{I}(15)$ & $\mathrm{R}(0)$ & $\mathrm{R}(10)$ & $\mathrm{R}(0)$ \\
\hline $\mathrm{P} 45$ & $\mathrm{I}(20)$ & $\mathrm{I}(17)$ & $\mathrm{I}(15)$ & $\mathrm{R}(0)$ & $\mathrm{R}(11)$ & $\mathrm{R}(0)$ \\
\hline $\mathrm{P} 46$ & $\mathrm{I}(16)$ & $\mathrm{I}(15)$ & $\mathrm{I}(17)$ & $\mathrm{R}(0)$ & $\mathrm{R}(10)$ & $\mathrm{R}(0)$ \\
\hline $\mathrm{P} 47$ & $\mathrm{I}(16)$ & $\mathrm{S}(21)$ & $\mathrm{R}(12)$ & $\mathrm{R}(0)$ & $\mathrm{S}(17)$ & $\mathrm{R}(0)$ \\
\hline $\mathrm{P} 48$ & $\mathrm{R}(13)$ & $\mathrm{I}(15)$ & $\mathrm{I}(15)$ & $\mathrm{R}(0)$ & $\mathrm{S}(18)$ & $\mathrm{R}(0)$ \\
\hline P49 & $\mathrm{I}(20)$ & $\mathrm{R}(13)$ & $\mathrm{I}(15)$ & $\mathrm{R}(0)$ & $\mathrm{R}(10)$ & $\mathrm{R}(0)$ \\
\hline P50 & $\mathrm{S}(30)$ & $\mathrm{S}(24)$ & $\mathrm{I}(15)$ & $\mathrm{R}(0)$ & $\mathrm{S}(25)$ & $\mathrm{R}(0)$ \\
\hline PS21 & $\mathrm{S}(22)$ & $\mathrm{S}(23)$ & $\mathrm{I}(20)$ & $\mathrm{I}(17)$ & $\mathrm{S}(32)$ & $\mathrm{I}(14)$ \\
\hline PS22 & $\mathrm{S}(26)$ & $\mathrm{S}(22)$ & $\mathrm{S}(28)$ & $\mathrm{R}(0)$ & $\mathrm{S}(26)$ & $\mathrm{R}(0)$ \\
\hline PS23 & $\mathrm{S}(24)$ & $\mathrm{S}(20)$ & $\mathrm{I}(20)$ & $\mathrm{R}(0)$ & $\mathrm{S}(26)$ & $\mathrm{R}(0)$ \\
\hline PS24 & $\mathrm{I}(17)$ & $\mathrm{S}(20)$ & $\mathrm{I}(15)$ & $\mathrm{R}(10)$ & $\mathrm{R}(13)$ & $\mathrm{R}(0)$ \\
\hline
\end{tabular}

Resistance (R) means the antibiotic lost its ability to inhibit the growth of bacteria, intermediate (I) means that the antibiotic works on bacterial growth moderately, and sensitive (S) means the antibiotic has the ability to inhibit the growth of bacteria. The scores are diameters of the inhibition zone in millimeters. 


\section{Drug resistance genes}

This study investigated the existence of $\beta$-lactamase resistance genes (CMY, OXA, CTX, SHV, TEM) in Pseudomonas bacteria by PCR amplification of their conservative region using gene specific primers (Ahmed et al., 2007, 2009). All Pseudomonas isolates showed negative results to three types of $\beta$-lactamase resistance genes, blaCTX, blaSHV and blaTEM. This means none of the isolates carry these types of resistance genes on their chromosome and plasmids. Out of 54 pseudomonas isolates, four isolates carried blaOXA gene (7.4\%), and two isolates were found to harbor blaCMY resistance gene (3.7\%) (Figure 6).

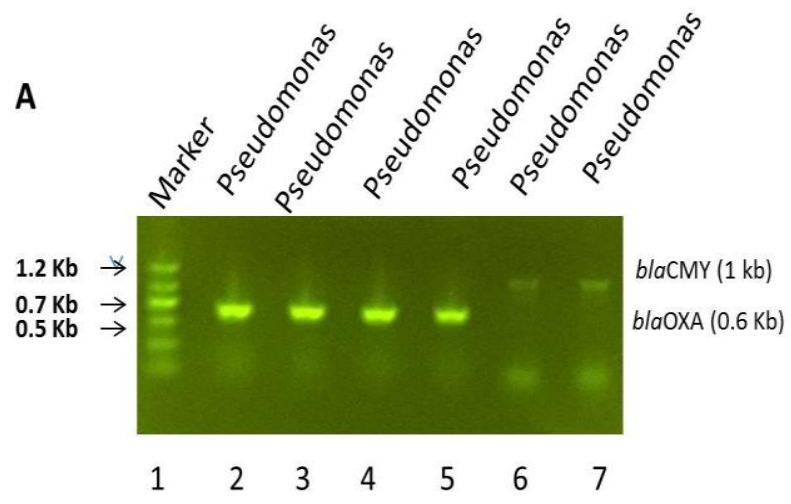

B

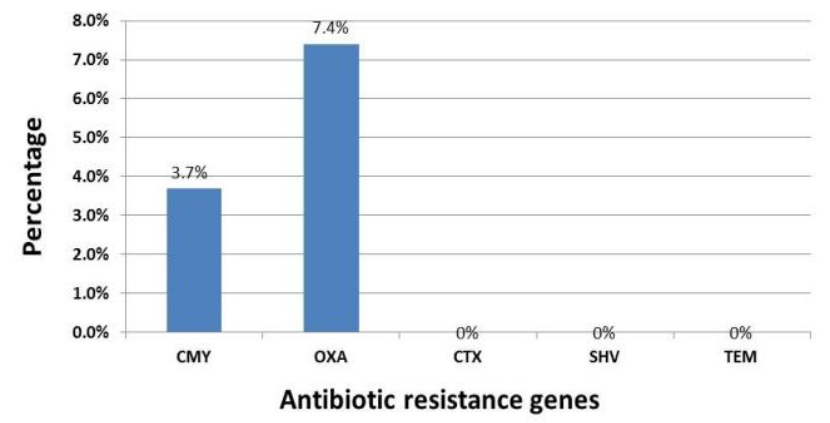

Figure-6. The rate of antibiotic resistance genes in Pseudomonas species.

A. Amplification of b-lactam resistance genes in Pseudomonas. bla OXA was recovered in four isolates (Lane 2-5) and the two genes of blaCMY were recovered in two isolates (Lane 6 and 7).

B. The rate of antibiotic resistance genes in Pseudomonas spp. isolated in the study area.

\section{Discussion}

Food poisoning syndrome results from ingestion of a wide variety of food and vegetables contaminated with pathogenic organisms such as bacteria, virus, parasite, and fungi, and their toxins and chemicals. Vegetables become contaminated by bacteria in fields during growing due to the use of organic fertilizer and contaminated irrigation water, or during harvesting, processing, distribution, sell and consumption (Beuchat, 2002; European Commission, 2002; Garg et al., 2010; Lerici et al., 2000).

Bacterial contamination rates are different according to the different type of vegetable and place (Garg et al., 2010). For example, carrots are cleaner than radishes because of its shape which cannot carry large amounts of dirt. It is also easierto clean and wash. Celery was found to be contaminated more than the other types of vegetables because celery is usually dirtier than carrot. This may be due to the fact that celery grows on the ground and is more exposed to environmental contamination. It also has a shape that is able to collect more bacteria and dust in its leaves compared to the other types of vegetables, including carrot and radish, which are smoother. In conclusion, all types of vegetables can become contaminated by different ratios, so proper washing of vegetables is necessary before consumption.

The total bacteria count in this study revealed that the contamination of vegetables by different types of bacteria is very high in the area. The average number of bacteria found in all the vegetables (50 samples) was 64,816 bacteria/gm. Coriander recorded the highest number of contamination $(89,720 \mathrm{cfu} / \mathrm{g})$, while the carrot had the lowest rate of contamination $(43,260$ $\mathrm{cfu} / \mathrm{g}$ ) (Figure 1). This is an indication that the vegetables in the area are not safe for consuming directly from the field, but needs proper washing and disinfecting to avoid catching diseases. Contamination of vegetables by the enteric bacteria is much higher than Staphylococcus species. The rate of contamination of Enterobacteriaceae group of bacteria, including Pseudomonas, was much higher (reaching 26,044 bacteria/gm CFU/gm in average), than Staphylococcus (reaching 5,612 CFU/gm in average) (Figures 2 and 3). This is an indication that vegetables are mostly contaminated by fecal bacteria in the area of study because farmers use sewage water for watering and growing of vegetables. Presence of pseudomonas in the soil is another reason. Sewage water is a carrier of large numbers of enteric bacteria, and it usually mixes with stream and river water in the area. Large areas of agriculture fields depend on these sources of water for irrigation. Therefore, the plants and vegetables become contaminated and carry huge 
numbers of bacteria, especially enteric bacteria. Consequently, they become a source of food borne diseases if not properly washed and cleaned before use. The previous finding agrees with the results because they confirmed that Pseudomonas species is the most common bacteria causing contamination in vegetables (Raposo et al., 2017).

The rate of total bacteria and pseudomonas in vegetables vary in different regions in the studied area. For example, vegetables in Qaladze are dirtier and more contaminated than those in Kalar. This can depend on the freshness of water that is used for irrigation, or the farmer's responsibility by taking care of the vegetables during processing and transportation. Irrigation by sewage water is common especially around big cities, which causes heavier contamination of vegetables in some areas such as Sulaimani and Qaladze. In contrast, Chamchamal uses well water (clean water) for irrigation, which is the main reason for having the lowest rate of bacterial contamination than the other areas. So the quality and sanitation of water is a key point to indicate the rate of contamination in vegetables.

The contamination of vegetables and fruits is related to many factors, starting from irrigation, harvesting, handling, processing, etc. (Kader and Barrett, 1996). The rate of Pseudomonas species was relatively high in this study, but the pathogenic species, Pseudomonas aurogenosa, was not recorded. All vegetable samples in this study contained Pseudomonas species bacteria, $100 \%$. The finding agrees with the previous conclusions that Pseudomonas bacteria is one of the common food spoilage bacteria in vegetables and fruits (Rahman, 2002; Raposo et al., 2017).

Antibiotic resistance occurrence was indicated for all Pseudomonas isolates recovered in this study. Therefore, by using antibiotic sensitivity testing, it was realized that most of the isolated bacteria became resistant for many antibiotics in different ratios. The highest resistance was to amoxicillin and amoxycilin/clavulanic acid, which reached AX25 $\% 98.2$ and AMC3 \%96.4, respectively (Figure 5). These resistance bacteria may be sourced from fecal contamination of sewage water or maybe are natural environmental bacteria, but nevertheless have developed resistance against many antibiotics. These resistant bacteria are problematic if passed into the population because they become a source of infection and treatment of patients will be impeded due to the ability of resistance bacteria to reject antibiotics during treatment.
Most of the reasons of bacterial resistance are due to having drug resistance genes. When these beta lactamase genes exist, it enables the bacteria to produce special proteins to degrade antibiotics (Grover et al., 2013; Khanna et al., 2012; Vaidya, 2011; Zhang et al., 2012). In this study, many Pseudomonas bacteria were found harboring bla-CTX and bla-OXa genes, which may help bacterial survival during antibiotic treatment (Figure 6). The existence of resistance genes in bacteria may come from bacteria of animal and human sources, rather than from soil, water and vegetables because natural bacteria of the environment carry resistance genes less often (Alaa et al., 2020).

\section{Conclusion}

It was concluded from the results that the rate of bacterial contamination of vegetables was very high, reaching 64,816 bacteria per gram of vegetable. The number of contamination by enteric bacteria (39640/gm) was more than Staphylococcus species (5,612 bacteria/gm). Total bacterial count revealed that the samples of Sulaimani town and Qaladze had the highest range of contamination due to using stream and river water mixed with sewage water for irrigation. The rate of vegetable contamination by Pseudomonas Spp. was $100 \%$ and it was mostly found on celery and radish at a high range. The rate of resistance of Pseudomonas is very high against many types of antibiotics, AX25 (\%98.2) and AMC3 (\%96.4). In addition, two types of beta lactamase resistance genes, blaOXA and blaCMY, were recovered in Pseudomonas. Finding a large number of resistant bacteria in vegetables shows that the vegetables are not safe and are a threat to public health because the treatment will be difficult when people become infected with these bacteria through consuming contaminated vegetables.

\section{Acknowledgement}

We acknowledge the president of Sulaimani Polytechnic University and especially Assistant Professor Dr. Alan Faraydoon Ali for his great help and academic support to perform this research. Also, we would like to appreciate Mam Humanitarian Foundation for their financial and logistic support. 
Disclaimer: None.

Conflict of Interest: None.

Source of Funding: None.

\section{References}

Ahmed AM, Motoi Y, Sato M, Maruyama A, Watanabe H, Fukumoto Y and Shimamoto T, 2007. Zoo animals as reservoirs of gram-negative bacteria harboring integrons and antimicrobial resistance genes. Appl. Environ. Microbiol. 73(20): 6686-6690.

Ahmed AM, Shimabukuro H and Shimamoto T, 2009. Isolation and molecular characterization of multidrug-resistant strains of escherichia coli and salmonella from retail chicken meat in Japan. J. Food Sci. 74(7): 405-410.

Alaa AR, Solhan MA, Lalan RM, Hiwa L,Mhamad NR, Niga KHM, Awat JN, Salar A, Brwa HRQ, Daryan KKH and Taib AHS, 2020. The antibiotic Resistance pattern and molecular characterization of bla CTX and TEM genes of E. coli idolated from different hosts based on the rate of antibiotic consumption in Sulaymaniyah/Iraq. Appl Ecol. Environ. Res. 18(5): 6025-6040.

Alzoreky NS and Nakahara K, 2003. Antibacterial activity of extracts from some edible plants commonly consumed in Asia. Int. J. food Microbiol. 80(3): 223-230.

Anonymous, 2014. United States food and drug administration (USFDA). Online Bacteriological Analytical Manual Revised Edition, 8th Ed, Arlington: US Food and Drug Administration. Http://Www.Fda.Gov/Food/FoodScienceResearc h/Laboratory Methods/Ucm070080.Html. Accessed on 9 Dec 2014.

Beuchat LR, 2002. Ecological factors influencing survival and growth of human pathogens on raw fruits and vegetables. Microbes Infect. 4(4):413423.

Borch E, Kant MM and Blixt Y, 1996. Bacterial spoilage of meat and cured meat products. International J. food Microbiol. 33(1):103-120.

Dainty RH and Mackey BM, 1992. The relationship between the phenotypic properties of bacteria from chill-stored meat and spoilage processes. J. Appl. Bacteriol. 73(21):103-114. DOI: 10.1111/j.1365-2672.1992.tb03630.x

Dashti AA, Jadaon MM, Abdulsamad AM and Dashti HM, 2009. Heat treatment of bacteria: A simple method of DNA extraction for molecular techniques, Kuwait Med. J. 41(2):117-122.

El-roos NAA, Abou KF and Yazid EL 2013. Molecular Characterization of Pseudomonas aeuginosa Isplated from Milk. Assiut Vet. Med. J. 59(139):14-22.

European Commission, 2002. Risk Profile on the Microbiological Contamination of Fruits and Vegetables Eaten Raw. Report of the Scientific Committee on Food, SCF/CS/FMH/SURF/Final, 2002,

Http://Ec.Europa.Eu/Food/Fs/Sc/Scf/Out125 En.Pdf.

Fan X, Niemira BA, Doona CJ, Feeherry FE and G RB, 2009. Microbial Safety of Fresh Produce. Ames, Wiley-Blackwell. Iowa: IFT Press.

FAO/WHO 2005, 2005. Food Safety Risk Analysis, an Overview and Framework Manual: meeting report, Rome. Food and Agriculture Organization of the United Nations/ World Health Organization. Available at: www.Fao.Org/Es/ESN/Index_en.Stm.

Franzetti L and Scarpellini M, 2007. Characterisation of Pseudomonas spp . isolated from foods. foods. Annal. Microbiol. 57(1):39-47.

Gallo L, Schmitt E and Schmidt LW, 1998. Microbial spoilage of refrigerated fresh broilers. I. Bacterial Flora and Growth during Storage. Lebensm. Wiss. U- Technol. 21(4):216-223.

Garg N, Garg KL and Mukerji KG, 2010. Laboratory Manual of Food Microbiology. I.K. International Publishing House, New Delhi, India.

Grover N, Sahni AK and Bhattacharya S, 2013. Therapeutic challenges of ESBLS and Ampc betalactamase producers in a tertiary care center. Med. J. Armed Forces India. 69(1):4-10.

Huis in 't Veld JH, 1996. Microbial and biochemical spoilage of foods: an overview. Int. J. Food Microbiol. 33(1):1-18. DOI: 10.1016/01681605(96)01139-7.

Kader A and Barrett D, 1996. Classification, composition of fruits, and posharvest maintenance of quality. In: L.P. Somogyi, H.S. Ramaswami, and Y.H. Hui, Eds., Processing Fruits: Science and Technology, Vol 1, Lancaster, PA: Tchnomic Publishing Company. p.1.

Khanna N, Boyes J, Lansdell PM, Hamouda A and Amyes SGB, 2012. Molecular epidemiology and antimicrobial resistance pattern of extendedspectrum- $\beta$-lactamase-producing

Enterobacteriaceae in Glasgow, Scotland. J. Antimicrob. Chemother. 67(3)573-577. 


\section{Omer Ahmed Ghafour et al}

Lerici CR, Nicoli MC and MA, 2000. The 'weight' given to food processing at the 'Food and Cancer Prevention III' symposium. Italian J. Food Sci. 12(1):3-7.

Mohammed GMO, Megahed AA and Nasr SS, 2015. Bacteriological and molecular detection of pseudomonas species from raw milk sold in PortSaid City markets. Egypt. J. Chem. Environ. Health. 1(1):986-1002.

Molina G and Pimentel MR, 2013. Pseudomonas : a promising biocatalyst for the bioconversion of terpenes. Appl. Microbiol. Biotechnol. 97:18511864.

Pathogens F, Pezzoli L, Researcher I, Elson R, England PH, Fisher IST, England PH, et al,. 2014. Packed with Salmonella - Investigation of an International Outbreak of Salmonella Senftenberg Infection Linked to Contamination of Prepacked Basil in 2007. Food borne Pathog. Dis. 5(5):661668. DOI: https://doi.org/10.1089/fpd.2008.0103.

Rahman MS, 2002. Handbook of Food Preservation. $2^{\text {nd }}$ ed. CRC Press, Taylor \& Francis Group, FL, USA.

Raposo A, Pérez E, de Faria CT, Ferrús MA and Carrascosa C, 2017. Food spoilage by pseudomonas spp.-An overview. In Foodborne Pathogens and Antibiotic Resistance. Singh, O.V., Ed.; JohnWiley \& Sons, Inc. Hoboken, NJ, USA, pp. 41-58.

Taylor P, Mead GC and Adams BW, 1977. A selective medium for the rapid isolation of pseudomonads associated with poultry meat spoilage. British Poultry Sci. 18(6):37-41.

Vaidya V, 2011. Horizontal transfer of antimicrobial resistance by extended-spectrum $\beta$ Lactamaseproducing Enterobacteriaceae. J. Lab. Physicians. 3(1): 37-42.

Warburton DW, Bowen B and Konkle A, 1994. The survival and recovery of Pseudomonas aeruginosa and its effect upon salmonellae in water: methodology to test bottled water in Canada. Canadian J. Microbiol. 40(12): 987-992.

Zhang Y, Yang J, Ye L, Luo Y, Wang W, Zhou W, Cui Z and Han L, 2012. Characterization of Clinical Multidrug-Resistant Escherichia coli and Klebsiella pneumoniae Isolates, 2007-2009, China. Microbial Drug Resist. 18(5): 465-470. DOI: https://doi.org/10.1089/mdr.2012.0016

\section{Contribution of Authors}

Ghafour OA, Nawzad C, Khalaf JK \& Soor TAH: Conceived idea, data collection, data analysis, literature review and final proofreading

Bchkol NK, Sharif AL \& Watman SR: Designed research methodology, data collection, laboratory analysis and manuscript writing 